\title{
14. 自己免疫性溶血性㙰血の臨床
}

昭和大学藤が丘病院内科 小峰光博

自己免疫性溶血性負血（AIHA）は今世紀初 頭には病態が認識されていたが，中間点近くに なって抗グロブリン (Coombs) 試験の導入に より病態の枠付けや診断が飛躍的に進展した. その後, 病態生理の解明が進められ，1950年代 には副腎皮質ステロイドの卓効が知られ，多大 の福音がもたらされた。引き続き病因・病態発 生の多様性が明らかにされてきたが, 臨床的に 観察される病態を包括的・一元的に説明する根 本的な機序の解明にはまだ距離がある．治療法 についても，ステロイド薬から半世紀を経た今 日なお基本的な選択肢にみるべき展開を経ない ままこの世紀を終えようとしている。

AIHAは抗赤血球自己抗体の出現によって特 徽づけられるが, 病像は自己抗体の性状によっ て規定される．温式抗体によるものを狭義の AIHAとし，冷式抗体によるものに寒冷凝集素 症と発作性寒冷へモグロビン尿症とがある。日 常診療で頻繁に遭遇する疾患ではないが，決し てまれでもない，診断には，溶血性貧血全般に
共通する症状所見があり, 患者赤血球の直接 Coombs試験を調べることがキーとなる.ウイ ルス感染や薬剤, SLEなどの自己免疫疾患，リ ンパ増殖性疾患などを背景にもつ場合と原因不 明の特発性とがあり,さらに急性一過性のこと と慢性経過をとることとがあり, 臨床病態に大 きな幅があることの理解が必要である。それは 成因上の多様性とも密に関連すると考えられ る.

薬物療法として副腎皮質ステロイド薬が最も 信頼できる治療法であるが, 摘脾, 免疫抑制薬 などの補助療法を上手く組み合わせて対処すれ ば患者管理上の収穕は大きい。厚生省研究班の 追跡調查では，特発性温式AIHAの 10 年後の生 存率は70\%，直接Coombs試験の陰性化率は55 \%の成績が得られている.

病因・病態発生の一層の理解とそれに基づい たより安全で特異性の高い治療法の開発が今後 の問題である.

\section{5．慢性膵炎の病態と治療}

\section{名古屋大学第二内科 早川哲夫}

慢性膵炎は慢性, 進行性の膵の炎症であるが， 急性萊炎から慢性膵炎に移行することはまれ で，特に，アルコール性膵炎では急性腪炎とし て発症しても，これはすでにある慢性膵炎の素 地の上に発症したものであり，慢性膵炎の急性 増悪であるとの見方が支配的であった.しかし， この数年, アルコール性苹炎の中にも急性荋炎 として発症しても, その後軽快し, 慢性膵炎に
進展しない例も報告され, 急性膵炎と慢性荤炎 の疾患概念も以前とはやや様子が変わってき た. 最近ではnecrosis-fibrosis sequence, すな わち, Comfortらが1946年に提唱した大小の急 性膵炎発作の反復を経て慢性搭炎に進展すると いう慢性再発性荤炎の概念が復活してきた。 1996年には遺伝性膵炎におらる遺伝子異常が明 らかとなり，第 7 染色体の長腕にあるcationic 
trypsinogenの遺伝子の点変異によりトリプシ ノーゲンの117番目のアミノ酸残基がアルギニ ンからヒスチデンに置換されていることが判明 した.このためトリプシンが自己消化による失 活を受け難くなり，トリプシン活性の高值が持 続し，辚炎が発症すると推定される．以上の上 うに，病因や病態の面ではこれまでの古典的な 概念が新たに確認されたように思う。医療に求
められるものは, 安全性, 確実性, 経済性であ ろう.これらの条件をみたす診断法, 治療法の 出現が慢性茦炎でも期待されている。

自験例および厚生省特定疾患調查研究班の全 国集計データ，米国消化器病学会からの慢性膵 炎の疼痛管理の指針などから慢性荤炎の病態と 治療の最近の動向について述べる予定である。

\section{6. 巣状系球体硬化症の病態と治療}

\section{奈良県立医科大学第一内科 土肥和紘}

巣状系球体硬化症（FSGS）は，予後不良の 難治性ネフローゼの代表疾患であるが，治療反 応性によって子後が大きく異なるという特徽が ある．従来の報告では，非寛解例の60～70\%は 約10年の経過で末期腎不全に移行するが, 寞解 例では末期腎不全への移行が稀とされる.一方， 寛解導入率は，報告によって異なるが，的50\% にすぎない。したがって，寛解導入率を改善す ることがFSGS治療の最重要課題になるが, 治 療反応例あるいは治療抵抗例を治療前に予測す ることも臨床の場では極めて重要といえる。そ こで, 厚生省特定疾患進行性腎障害調查研究班 は，ネフローゼ症候群を呈する成人FSGSの全 国アンケート調查を実施し, 221例の転帰と予 後予測因子について検討した。この全国アン ケート調查は，1）20年生存率が約40\%にすぎ ない，2）腎生検での間質障害が独立した子後 不良の危険因子（相対危険度6.05）である，3） ネフローゼ症候群の転帰からみた腎機能の予後 は, 従来の報告と同様に, 不完全寛解项型と無
効例に比して完全寛解と不完全寛解I型例で有 意に良好である，4）しかし，予後を改善させ る治療法はみられない，という本邦でのFSGS の現状を明らかにした. 一方，私どもの教室は， ネフローゼFSGS症例についての多変量解析か ら，間質病変に加えて糸球体肥大も独立した予 後不良の危険因子になることと，種々の免疫抑 制薬に中等量（15〜20mg/日）の副腎皮質ステ ロイドを 6 カ月以上の長期間投与する治療法 で，ネフローゼFSGSの60\%を越える症例が完 全寛解あるいは不完全寛解 I 型に移行したとい う良好な成績を得ている，さらに，ネフローゼ FSGS例は，分節状硬化性病変の出現する以前 から糸球体肥大を呈するが，寛解導入後に糸球 体肥大が消失することを報告した．また，FSGS 例での系球体肥大は予後予測のみならず病因に おいても重要であることも明らかにした。

本講演では，本邦に扔ける成人巣状糸球体硬 化症例の現状を紹介したい. 